\title{
In Memory of Hugh Boyd
}

by Ruth and Peter McLintock, Winnipeg

Hugh Boyd was a man much loved by everyone who knew him. He was pleasantly eccentric in some ways, and had a great interest in and knowledge of the outdoors. But birding was his favorite hobby and when the Boyds lived in Regina in the early 1930's, Hugh was one of the city's most knowledgeable birders.

The one thing his friends remember best about him is that in all their experience they had never known anyone as absolutely accurate and meticulous about identifying. The Regina Natural History Society had a standing joke that Hugh never identified a bird until he had counted every feather. Once you had seen a bird with Hughie, you never mistook it again as long as you lived, for you looked at it from every angle and checked it against all the books. When you saw it again you would know it. If Hugh wasn't absolutely convinced of a bird's identity, he refused to record it.

On one occasion a group of society members were out on a hike and saw, they were convinced, a dickcissel. Everybody was sure except Hugh. The bird flew off before he was convinced, so he refused to record it; and nobody else had the nerve to put it down either. In this respect Hugh was fussy. But it wasn't a sticky fussiness; he was always great fun to be with.

In those days the Boyds lived in a big old-fashioned apartment in Victoria Court, that had a fireplace in the living room. One of the nicest things that could happen to you in those days was to be invited to the Boyds for an evening, after birding, or in the winter time.

The Boyds always asked in a congenial group and you spent the evening around the fire talking about things that interested everyone-aided by Hugh's large and comprehensive natural history library. Helen, his wife, was (and is) a first-rate cook, which helped.

Some 15 years ago, long after the Boyds had moved from Regina to
Ottawa, the writers also spent a year in the capital city. Their first Christmas Day, which might have been a rather lonely one, they spent at the Boyds. For Hugh never forgot his old friends and never forgot the West (about which he was considered, rightly, in Ottawa to be an expert). Christmas dinner at the Boyds that day was an hour and a half late, for, as usual, Hugh had forgotten the time and had taken his boys skiing in the afternoon. This was one of his idiosyncrasies - he was never on time for anything; and the later the day wore on, the further behind Hugh got in his schedule.

His love of the outdoors, and his love of walking, stayed with him to the end. Only a couple of months before his death he was in Charlottetown with a group of newspaper people, reporting the Centenary celebrations there. The group stayed at a motel some three miles from the city. At 7 a.m. on the morning after their arrival, a Winnipeg journalist was horrified (and flattered) to be aroused by Hugh, who insisted that the three-mile walk into town would do them both good.

He was quite an unforgettable man and his memory will always be with those who were lucky enough to be among his friends.

Editor's Note: On December 15, 1964, the Regina Leader-Post carried the news of the death of Hugh Boyd in Ottawa the previous day. Mr. Boyd started his career with the Leader-Post in 1929 , two years later became publicity and advertising director for the Saskatchewan Co-operative Wheat Producers, and in 1939 joined the CBC staff as the first Prairie regional farm commentator. Later he served on the staff of the Winnipeg Free Press and the Ottawa Citizen. Many Blue Jay readers in the West will remember him as the Prairie regional farm commentator, and even before this as the writer of the spirited column "About Birds" in the Leader-Post from 19331937. Boyd's columns in the files of the Leader-Post were consulted for records for the Birds of Regina. 